\title{
Como jornalistas lidam com fontes disponíveis nas redes sociais do ciberespaço
}

Thaísa Cristina Bueno

BARONE, V. L.

Os sítios de redes sociais no processo de produção da notícia e seu uso no jornalismo sul-mato-grossense.

Portugal: Labcom, 184 p., 2016. os sítios

DE REDES SOCIAIS

NO PROCESSO

DE PRODUÇÃOO

DA NOTÍCIA

E SEU USO

NO JORNALISMO

SUL-MATO-GROSSENSE

\section{䀧}

Resumo: Este livro debate como os jornalistas têm se relacionado com as fontes disponíveis nas redes sociais para entender sua influência na rotina produtiva, bem como o nível de confiabilidade que os profissionais dão a essas fontes acessadas diretamente no ciberespaço. A pesquisa tem como foco a mídia de Mato Grosso do Sul, mas os resultados permitem olhar criticamente para a realidade de veículos no interior do Brasil.

Palavras-chave: fontes; redes sociais; Mato Grosso do Sul.

Abstract: How do journalists deal with sources available on cyberspace social networks - This book discusses how journalists have been related with the sources available in social networks to understand their influence on the productive routine, as well as the level of trust that professionals give to those sources accessed directly in cyberspace. The research is focused on the media of Mato Grosso do Sul; nevertheless, the results allow us to look critically at the reality of vehicles within the interior of Brazil.

Keywords: sources in journalism; social networks; Mato Grosso do Sul. 
Muito já foi falado sobre redes sociais e jornalismo. Nomes como Machado (2003), Recuero (2009), Santaella e Lemos (2010) são apenas alguns exemplos de pesquisadores nacionais a enveredarem com propriedade nessa área. Sem a pretensão de redefinir os paradigmas já apresentados por esses e outros pensadores da comunicação, Os sítios de redes sociais no processo de produção da notícia e seu uso no jornalismo sul-matogrossense, do jornalista e pesquisador Victor Luiz Barone, parece ampliar o debate em torno do assunto contribuindo para fechar arestas em dois pontos que considero afortunados no conjunto da obra: a aproximação, necessária, da discussão que permeia o uso das redes socais na rotina dos veículos não por meio de possibilidades ou conjecturas teóricas, mas, efetivamente, a partir do olhar dos próprios jornalistas; e, também, o modo como acolhe uma reflexão sobre o tema tendo como recorte a imprensa de interior. Com essas duas peculiaridades, que afiançam um diferencial a esta publicação, o livro debate, mais fortemente, como os jornalistas têm se relacionado com as fontes disponíveis nas redes sociais para entender sua relação na rotina dos jornais e como os profissionais lidam com esse acesso do ponto de vista da credibilidade e da aceitação.

O livro, resultado de uma pesquisa de Mestrado no programa da Universidade Federal do Mato Grosso do Sul (UFMS), em Campo Grande (MS), tem a chancela da editora LabCom, da Universidade da Beira Interior, em Portugal, que já publicou outros nomes importantes da área, como a pesquisadora Lia Seixas (2009) e Marcos Palácios (2016). A obra, que integra a série intitulada Jornalismo, pode ser acessada no endereço da editora (www.labcom-ifp.ubi.pt) e está disponível nos formatos impresso, PDF (gratuito) e Epub.

A premissa central da pesquisa busca entender se os jornalistas têm, verdadeiramente, usado as possibilidades de acesso às fontes por meio das redes sociais para ampliar a pluralidade dos discursos, além de tentar descobrir como esses profissionais se relacionam com elas, bem como o nível de confiabilidade que Ihes afiançam. Para isso foram ouvidos 50 jornalistas oriundos dos dez maiores veículos de comunicação daquele Estado, localizado na região central do país. Em 167 páginas (as demais são anexos), o livro arranja todo o seu conteúdo em cinco capítulos: Redes Sociais e Redes Sociais na Internet; Fontes, Internet e Rotinas Produtivas; Oficialismo e Pluralismo no Discurso Jornalístico; A Internet como Espaço e Esfera Pública; e Os jornalistas de Mato Grosso do Sul e os Sítios de Redes Sociais.

Embora ainda encontremos um ranço da dissertação no volume publicado, com a divisão bem marcada entre a parte teórica e a empírica, o fato de o diálogo com o campo já iniciar-se no terceiro capítulo garante fôlego e deixa a leitura mais agradável. Além disso, para quem não é familiarizado com os temas internet e redes sociais, os dois primeiros capítulos são uma porta de entrada para conhecer o assunto. O autor resgata conceitos, dialoga com autores não só da comunicação mas também das ciências sociais, e busca reunir informações sobre a contextualização histórica que permitiu a construção do sentido contemporâneo do meio e da ferramenta. 
Se parece uma escolha bastante introdutória, torna-se relevante comentar que o livro não tem uma introdução. Quem faz essa apresentação do texto é o professor Elias Machado, um dos membros da banca de defesa da pesquisa que resultou no livro. Um prefácio que, diga-se de passagem, não poderia ser melhor exposto, afinal, Machado é autor de O ciberespaço como fonte para os jornalistas (2003), uma publicação inovadora em seu tempo e que tem boa parte das suas proposições ratificadas no campo por meio da pesquisa de Barone, em particular no que se refere às redes sociais ganharem status de fonte e influenciarem fortemente a rotina dos veículos.

Conforme informa o autor no livro:

A maioria dos jornalistas entrevistados concordou que a participação dos usuários nos Sítios de Redes Sociais (SRS) influencia na produção da notícia $(86,0 \%)$ e afirmou ter identificado em algum momento de sua prática profissional informações com valor-notícia publicadas em primeira mão nos SRS (86,0\%). Um dado importante para o escopo desta pesquisa é o percentual de entrevistados que apontou a origem destas informações em usuários ou entidades não ligadas ao Jornalismo (72,1\%) (MACHADO, 2003, p. 103).

Mas essa não é a única curiosidade da obra, um dos pontos que levanta boas indagações é sobre o conservadorismo encontrado na fala e na postura da maioria dos profissionais pesquisados no que diz respeito à relação com as fontes. Conforme narra-se no livro, a maioria diz que usa as redes, mas confia, mais enfaticamente, nas informações publicadas no ciberespaço pelas fontes oficiais. Até aí não há grande surpresa, mas a justificativa para isso é que parece ser bem peculiar: "As fontes oficiais são as 'mais confiáveis' por serem oficiais". A maioria dos entrevistados atribuiu maior credibilidade a esta informação se ela for proveniente de jornalistas e assessorias de imprensa. Observouse, ainda, uma desconfiança acentuada na informação disseminada nas redes por pessoas não ligadas ao Jornalismo.

Há, ainda, uma tendência de parte dos jornalistas entrevistados em se eximir da reponsabilidade sobre a informação prestada por uma fonte oficial, como se o simples uso das aspas e a atribuição da informação a esta qualidade de fonte tirasse do jornalista a responsabilidade sobre o que está sendo divulgado. (ibidem, p. 73)

Uma outra contribuição da pesquisa sobre o universo sul-mato-grossense é que, apesar de a maioria dos entrevistados não ver diferença entre as fontes oficiais dentro ou fora das redes, a maioria considera que o espaço virtual ainda gera desconfiança porque encontram "nestes ambientes um certo grau de descompromisso". Isso leva a pensar que esses jornalistas estão, ainda, muito presos ao paradigma que dualiza real e virtual ou que não estão, ainda, muito familiarizados com a rotina de integrar as redes como fonte de informação. 
Além desses pontos apresentados, outras peculiaridades, além de um perfil detalhado de quem são hoje os jornalistas que atuam no mercado sul-mato-grossense complementam a obra. E, embora seja o livro trate das práticas dos profissionais de Mato Grosso do Sul, não chega a ser um livro estritamente regional porque como outros estudos de caso pode servir de base para ampliar olhares para realidades semelhantes em outras regiões fora dos grandes centros. Mais que isso, a pesquisa contribui para que olhemos as relações e apropriações da mídia, suas rotinas e suas deficiências para além dos modelos da grande mídia ou para a produção que tem como recorte veículos estrangeiros, e para que olhemos de modo aprofundado para o interior do Brasil. E só isso já faz do livro uma produção necessária.

Thaisa Cristina Bueno é professora do Curso de Jornalismo da Universidade Federal do Maranhão; é doutora em Comunicação pela PUC-RS e mestre em Letras pela UFMS.

thaisabu@gmail.com

\section{Referências}

MACHADO, E. O ciberespaço como fonte para os jornalistas. Salvador: Calandra, 2003.

MARTINS, E. ; PALACIOS, M. Ferramentas para análise de qualidade no ciberjornalismo - Volumes 1 e 2. Portugal: Labcom, 2016.

RECUERO, R. Redes sociais na internet. Porto Alegre: Sulina, 2009.

SANTAELLA, L.; LEMOS, R. Redes sociais digitais: a cognição conectiva do Twitter. São Paulo: Paulus, 2010.

SEIXAS, L. Redefinindo os gêneros jornalísticos: proposta de novos critérios de classificação. Portugal: LabCom, 2009. 